日消外会誌 $11(8): 621 \sim 625,1978$ 年

特 $4^{*}$

食道静脈瘤に対する直達手術の成績

$$
\text { ならびに手術適応の検討 }
$$

\author{
新潟大学第 1 外科 \\ 吉田夆介高野 征雄 武滕 輝-
}

\title{
CLINICAL EXPERIENCES OF ESOPHAGEAT TRANSECTION COMBINED WITH DEVASCULARIZATION FOR ESOPHAGEAL VARICES ; WITH SPECIAL REFERENCE TO THE INDICATIONS OF EMERGENCY AND PROPHYLACTIC SURGERY
}

\author{
Keisuke YOSHIDA, Yukio TAKANO and Terukazu MUTO
}

I st Department of Surgery, Niigata University, School of Medicine

索引用語 : portal hypertension, esophageal varices, esophageal transection, proximal gastrectomy, paraesophago-gastric devascularization.

はじめに

食道静脈嗐に対する直達手術は静脈瘤結禁術やWal$\mathrm{ker}^{1)}$ の食道離断術が欧米で放棄された後も, shunt 手 術に対する批判”が強かったわが国に和いて検討が進め られ，食道静脈瘤への血行路を壁内・壁外において可及 的に遮断することに主眼を扎いた今日の術式が確立され るに至っている．最近では欧米でも再評価の気運がみら

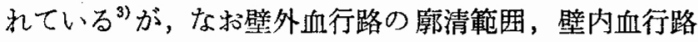
の遮断部位などをめぐってアプローチや術後合併症の防 止対策，止血効果の判定など多くの論争点が残されてい る.われわれす食道離断術を中心に直達手術75例の経験 をむとに，その手術摘応と問題点について緊急手術およ び予防手術を中心に検討したので報告する。

$$
\text { 症例 }
$$

昭和152年 8 月をでに 経験した直達手術例は肝硬変 42 例, 肝線維症28例, 肝前性門脈陚塞症 4 例, Budd-Chiari 症候群 1 例の計75例で，手術時期別には緊急手術17例， 待期手術40例, 予防手術18例であった（表 1). 施行術 式は経胸的食道離断術に傍食道胃上部血行房清と脾適を 付加したもの（食道離断十血行廍清群）36例, 経胸的食 道離断術のみ,またはこれに脾摘を加えたもの（食道離

*第11回日消外総会シンポ II 食道静脈瘤の直達手術とその適応

\begin{tabular}{|c|c|c|c|c|c|}
\hline & 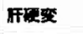 & 旰䅧倠症 & 旰前性 & Budd-Chiari & It \\
\hline 粲急手䚘 & $13(3)$ & $3(0)$ & $1(0)$ & 0 & $17(3)$ \\
\hline 特期手穌 & $20(2)$ & $17(2)$ & $3(0)$ & 0 & $40(4)$ \\
\hline 予游手術 & $\theta(0)$ & $8(0)$ & 0 & $1(0)$ & $18(0)$ \\
\hline 暗 & $42(5)$ & $28(2)$ & $4(0)$ & $1(0)$ & $76(7)$ \\
\hline
\end{tabular}

表 1 直達手術症例 1977. 8

断群) 23例, 胃上部切除術14例, 胃離断術 1 例, 胃全摘 術（胃癌合併）1例であった。

食道離断十血行廓清群では東大 2 外科 $^{(4)}$ 法に準じ口側 は下肺静脈, 肛門側は左胃動脈最終枝と左右胃大網動脈 境界を結ぶ線を目標に血行㟨清を行い，食道は食道裂孔 の口側 1 ないし $2 \mathrm{~cm}$ で笳層の右側半周を残して離断し， 粘膜を5ー0または 4-0綟系にて密な結節縫合あるいは 全周 8 分割の連続縫合で再吻合した. 胃上部切除 ${ }^{5)}$ 群で は食道裂孔の口側から胃は上述の線までの範囲血行邡清 之噴門直上から 2 ないし $3 \mathrm{~cm}$ 前後をでの噴闍側胃切除 を行い，残胃前壁に端側食道胃吻合を行った。いずれの 場合も迷走神経幹は温存に務めたが，その確認は困難な 場合もあり，原則的に幽門形成を付加した。

$$
\text { 成 }
$$

1. 術式と手術成績

食道離断十血行搼清群では手術死亡 2 例 (5.6\%), 術 
表 2 食道離断術（脾摘十血行廓清）の成績

\begin{tabular}{|c|c|c|c|c|c|c|}
\hline & 证90 & 年的歌 & 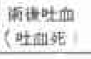 & 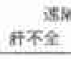 & 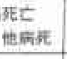 & 生开班 \\
\hline 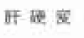 & 21 & 0 & 0 & 3 & o & 10 \\
\hline 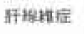 & 12 & 2 & 0 & 1 & 0 & 9 \\
\hline 析酶些 & 3 & 0 & 0 & 0 & 0 & 3 \\
\hline it & 36 & 2 & $0<1$ & 4 & 0 & 30 \\
\hline
\end{tabular}

後食道静脈瘤出血 0 , 遠隔死亡 4 例, 生存率 $88 \%$ (49年 末穼での酎術者14例における 3 年生存率 $92.8 \%$ ）之良好 な成綘であった（表 2 ).手術死亡例はいずれも肝線維症 (待期手術) で，死因は脳出血と門脈血栓に続発した小 晹穿孔であり (表 5), ともに腹部操作後の合併症による ものであった. 遠隔死亡は肝硬変の 3 例が肝癌 ( 4 年) と肝不全（ 2 年 7 力月 6 力月）で, 肝線維症の 1 例が 肝不全 ( 4 年11カ月) でそれぞれ死亡したものである.

食道離断群では手術死亡 3 例 (13\%), 術後吐血 4 例 (耐術者の $15 \%$ ), 遠隔死亡7 例, 生存率65\%（49年末ま での耐術者16例に括ける 3 年生存率56.2\%) であった。 直達手術を採用した初期の症例が多いこと, 緊急手術例 が多く(10例)，李た肝障害のため開腹操作を断念した狟 例がこの群に含をれることが成績に反映しているものと 思われる（表 3).

胃上部切除群はいまだ症例が少なく，追跡期間も不卜 分であるが，手術死亡は肝癌合併肝硬変の1例 $(7 \%)$, 術後食道静脈瘤出血, 遠隔死亡共に現在まで 1 例も認め

表 3 食道離断術士脾摘の成績

\begin{tabular}{|c|c|c|c|c|c|}
\hline & 拱到 & 手乘施亡 & 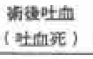 & 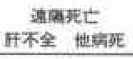 & 生帮明 \\
\hline 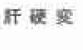 & 13 & 3 & $2(1)$ & 2 & 4 \\
\hline 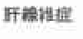 & 10 & 0 & $2(0)$ & 0 & 9 \\
\hline 旰堆性 & 0 & & 0 & & 0 \\
\hline at & 23 & 3 & $4(1)$ & 2 & 13 \\
\hline
\end{tabular}

表 4 胃上部切除術の成績

\begin{tabular}{|c|c|c|c|c|c|c|}
\hline & \multirow[t]{2}{*}{ 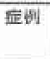 } & \multirow[t]{2}{*}{ 乎业死t } & \multirow{2}{*}{ 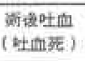 } & \multicolumn{2}{|c|}{ 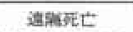 } & \multirow[t]{2}{*}{ 生教的 } \\
\hline & & & & 䀒不全 & 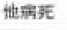 & \\
\hline If 楆 & 7 & 1 & 0 & 0 & 0 & 6 \\
\hline 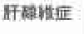 & E & 0 & 0 & $\circ$ & 0 & 6 \\
\hline the & 2 & 0 & 0 & 0 & 0 & 2 \\
\hline 竐 & 14 & 1 & 0 & 0 & 0 & 13 \\
\hline
\end{tabular}

表 5 手術死亡例

\begin{tabular}{|c|c|c|c|c|c|}
\hline 击 & * & 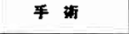 & 稀日 & 开 因 & at \\
\hline $1.47 \mathrm{~F}$ & ff $\bar{x}$ : & 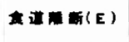 & 18 & 再出䘏・布不全 & 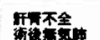 \\
\hline $2.42 \mathrm{M}$ & - & , (E) & 2 & $\mathbf{s} \equiv \mathbf{z}$ & 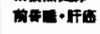 \\
\hline $3.80 \mathrm{~m}$ & - & - (年) & 23 & 賞合不全 & \\
\hline $4.83 M$ & - & 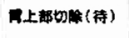 & 6 & 括不全·出血 & ffex \\
\hline $6.64 \mathrm{M}$ & - & W 断(E) & 9 & 整不全 & 整不䨝 \\
\hline $6.62 \mathrm{~F}$ & If & 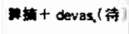 & 10 & 出 & \\
\hline $7.71 \mathrm{~F}$ & $\cdots$ & . (释) & 27 & 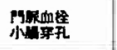 & \\
\hline
\end{tabular}

られない(表 4 ).

2. 手術時期と手術成績 (表 1 )

緊急手術 17 例中胃離断術の1 例（手術死亡）を除く16 例の経胸的食道離断術例では末期肝硬変と訮癌の各 1 例 を失ったのみで，意識障害を伴う高度肝障害例 2 例を含 め14例を救命しえた。出血時の状態から予後を予浿する ことは困難で諸所見陽性例中の手術死亡は，腹水 $3 / 11$, 黄底 ( $\mathrm{T} . \mathrm{B} \geqq 2 \mathrm{mg} / \mathrm{dl}$ ) $3 / 8$, 意識障害 $0 / 2, \mathrm{GOT} \geqq 1002 / 3$, $\mathrm{Alb} \leqq 3.0 \mathrm{~g} / \mathrm{dl}$ 3/9，の如くであり，救命例の T.B 最高 値 $9.4 \mathrm{mg} / \mathrm{dl}$, GOT 225, GPT 100, ICG 停滞率 $71.2 \%$, Alb 最低俌 $1.8 \mathrm{~g} / \mathrm{dl}$ であった。しかし祭急に食道離断術 を施行したのみで二期的に腹部血行部清を追加できなか った10例では，再出血20\%，肝不全死40\%と予後不良で あった。

予防手術18例の内訳は食道離断群 2 例, 食道離断十血 行廍清群 11 例, 胃上部切除群 4 例, その他 1 例（胃癌合 併例に対する胃全摘術)であった。現在まで手術死亡， 術後出血とるになく，遠隔死亡 2 例（生存率89\%) であ った.

待期手術施行例は食道離断群 11 例, 食道離断十血行廓 清群19例, 胃上部切除群10例の 40例で, 手術死亡は 4 例，10\%であった．速隔死亡は食道離断群で肝硬変の 2 例が，また食道離断十血行廓清群で肝硬変および肝線維 症の各 1 例が肝不全で死亡し，生存率89\%であった。

予防扣よび待期手術例に拈ける肝機能と手術成績をみ ると, 待期手術例のうち比較的術前状態良好な 2 例を脳 出血と門脈血栓で失ったため, 肝機能検查成績と予後と の間に明確な傾向は見出し難いが，T.B $4.0 \mathrm{mg} / \mathrm{dl}$ 以 上, ICG 消失率0.06以下では risk が高いと思われ（図 1)，とくに肝障害が関与したと思われる肝不全および 縫合不全による死亡例は ICG 消失率 0.06 以下に見られ た。

3. 術後合併症 
因 1 肝機能と手術成績（予防・待期手術）・手術 死亡
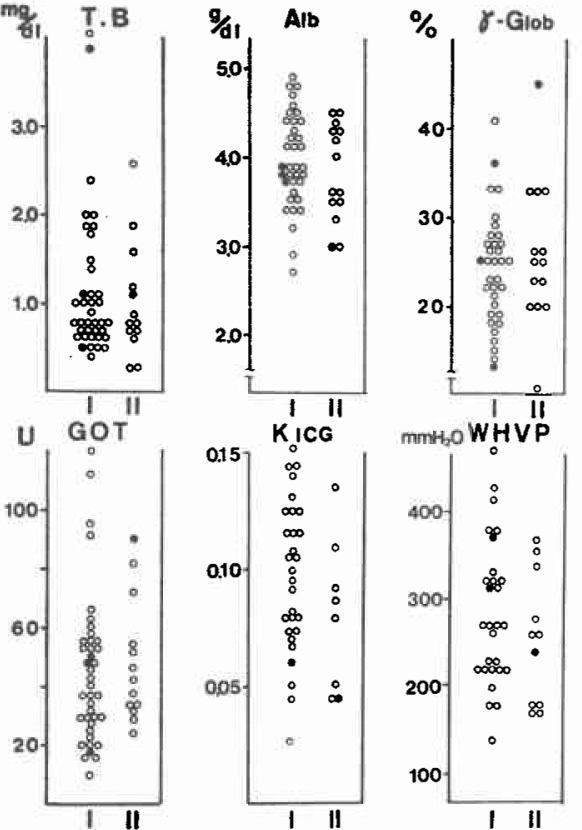

I食道離断術 || 胃上部切除術

表 6 術後合併症 （）死亡例

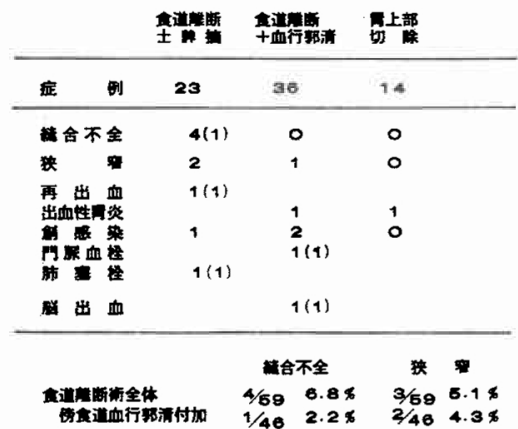

表 6 亿術式別にみた術後合併症を示した。死亡に直結 する重篤な合例症としては食道離断後の縫合不全, 脾摘 後の血栓症が重要であり，その他食道離断部の狄窄が 3 例 $(5.1 \%)$ にみられた，縫合不全，狭窄ともに胸膑内 で広く血行廓清を行い，食道吻合鎮子を用いて緊張のな い状態で密な縫合を行うようになってから著明に減少し ている.

術後後遺症の1つとして注目されている食道炎に比 いては, 術後 3 カ月以内の内視鏡観察で埕道離断十血
行廓清群 20 例中に 3 例の色調变化型, 胃上部切除群 9 例 中 1 例にビラン潰瘍型食道炎を諗めたが，3 カ月以上経 過例では食道離断+血行㟲清群 13 例中食道炎なく, 胃上 部切除群でる 9 例中 1 例飞色調変化型食道炎を認めたの みであった。しかし食道内压, $\mathrm{pH}$ 曲線では下部昇圧带 の圧低下 $(5 \mathrm{mmHg}$ 以下) を呈寸るるのが両群共約半数 にみられ今後の追跡観察の必要性を示唆した。

4. 食道静脈溜の内視鏡所見

吐血禁の汸る28淀例の食道内視鏡所見は図 2 に示すご とく, 門脈外科研究会の試案による stage 分類上, stage

図2 内視鏡所見 (出血例)

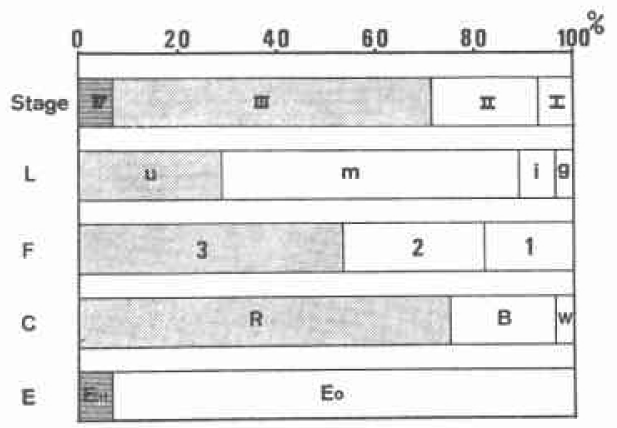

因 3 術後の食道静脈瘤内視鏡所見
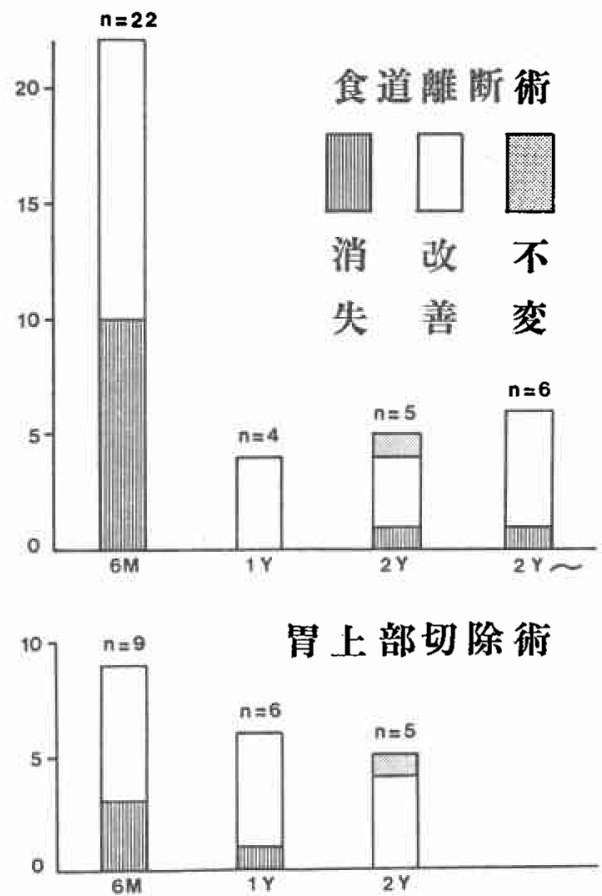
III, 高さ $\mathrm{Lm}$ (中部) 形態 $\mathrm{F}_{3}$ (結節状) が多く, 色調 Cでは胃静脈瘤出血の 1 例を除き赤色または青色静脈瘤 であった。びらんを伴ら食道炎は 2 例認められた。吐 血前の観察記録のある 6 例では 1 例を除き赤色静脈潪で あったが, 白色静脈溜として経過観察中の 1 例が 6 力月 後大量出血を来たし緊急手術が行われた。

術後の静脈瘤の消失は図 3 の如く, 食道離断+血行倣 清術後約半数に消失が, その他の症例にも著明な静脈湾

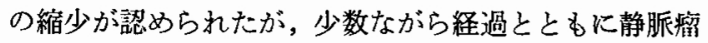
の再生傾向を示寸ものがあり,この傾向は男上部切除群 でも同様であった。今日まで両群ともに再出血は見られ ないが今後の観察が極めて重要と思われた。

\section{考察}

われわれは直達手術として二期分割により安全度が漓 く, かつ噴門機能脱落の危険性が少ない東大第 2 外科力 式に上る食道離断術を主として採用してき㐫。開股操作 に比べて開胸の侵襲が少ないことは，われわれの手術死 亡例が緊急手術を除き開腹後に多いこと, 開腹操作後腹 水貯溜などのため回復の䢭延する拉例がしばしばみられ ることなどから経験的にも知ることができるが，術後経 日的に ICG の失率を追跡した小林”らの成績はそれを よく裏付けている，祭急手術として施行した経胸的食道 離断術は止血效果，救命率の们で一応满定すべき成績で あった，吐血時にはできる限り保存的処瞋によって止血 を待ち，待期手術に持ち込むことが原則であるが，自験 例のらち長期間輸血を反復した症例の予後は不良であっ たことから，保存的処置による観察期間は48時間前後ま でと考えている．吖血時の手術適応については，胿機能 検査成績は出血による一時的增覀のため必らずしも参考 にでさない場合が多く，吐血前より肝不全の状態にあっ た場合を除き，バルンカテーテルにより48時問以内に止 血しえない時は積極的に食道離断術を施行するう針であ る.

しかし，祭急手術例の長期予後は不良であり，大量出 血による肝病変の增悪が予後に反映されたものと考えら れる成䋶であった，そのため道切な予防手術の邀応設定

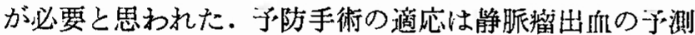
と手術の安全性の雨面から検討されるべきであるが，出 血の予測に関しては現在静脈湆の内視鏡所見が最も重視 されている，吐血歷ある腚例および吐血前観察例の内視 鏡所見から，出血飞最も関連性の㳭い因子は諸家多9の

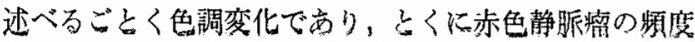

が高かった．しかし Lm, $\mathrm{F}_{3}$ の白出静脈蕾と判定した後 6 カ月で大星吐血と来たした症例も西り，形態や位置を 含めた局所々見と肝病変の進行性をる考虑した総合的判 断が必要と思われる。びらん（E）の頻度は少なかった

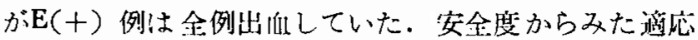
基集については，尒防手術の性格上全身状態，肝予備力

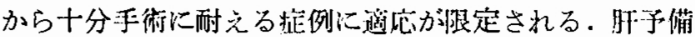
力の判定にはルチンの検查法として任素排泄能の倌頼性 が高いとされて扣り7，自験例については ICG 消失摔 0.06 二期分割手術の一底心安全限界之考えら九た．以 上の考察上り各時期における手術適応學淮を表 7 のごと く設定した。

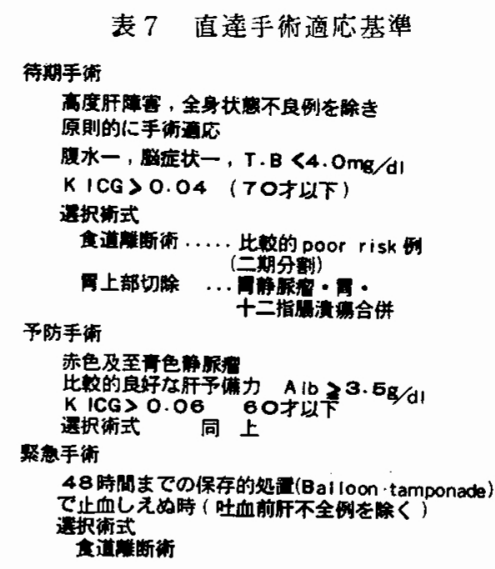

一方直達手術の問題点として, 再出血の防止と術後合 併症への対策がある．止血手術としての根治性について は，食道離断術の成績にみられる通り，血行廓清不十分 な症例に再吐血が多いことや定型的血行黁清後も静脈瘦 の再生傾向を示す例があることより，促来指摘して来た ごとく ${ }^{10)}$ 十分な倣食道・胃上部の血行遊清が最も重要と 思われた。とくに筋層の半周が離断されない食道離断術 では一層この点に留意し, 最も問題之なる食道裂孔部で は開胸および開腹時上下より十分重複するように血行郭 清を行う必要がある。

合併症として重要な縫合不全と狭窄は十分に広く血行 剚清を行って食道を遊離し，わ就われ考案した食道吻 合鉬子を用いて緊張のない状態で密に䋖合（粘膜下静脈 畋の結䕀は行わない)することにより著明に減少してお り，血行遊清に上る血流障害を愁念する必要はないと考 爷れる。 


\section{おわりに}

昭和52年 8 月までて経験した75例の直達手術の成績を もとに, 食道静脈瘤の手術適応について検討した。緊急 時経胸的食道離断術の救命率は高いが，長期予後は不良 であり，大量出血以前に予防的手術の必要性が感じられ たため, 手術の安全限界招よび内視鏡所見からみた静脈 瘤出血の危険度から予防手術適応基準の設定を試みた。 食道離断術の効果を確実にするためには広、範囲の血行 的清が重要であり，その経過の観察には食道内視鏡が最 る有用と思われた。胃静脈瘤または胃潰瘍合併例や開胸 不能例に試みてきた胃上部切除術の成績も添満足でき るものであり，今後適応を選びつつ経験を重ねたいと考 えている。

\section{文嗝}

1) Walker, R.M.: Esophageal transection for bleeding varices. Surg. Gynecol. Obstet., 118: 323-329, 1964.

2）木本誠二：門脈王光進症の手術法とその遠隔成 績。日外会誌, $67: 1743-1754,1966$.
3) Pierce, G.E. et al.: A transthoracic devascularization procedure for control of bleeding esophageal varices: Preliminary report. Amer. J. Surg., 134: 794-798, 1977.

4) 杉浦光雄汪か：食道離断術。外治, $37: 270$ $282,1977$.

5）山本貞博渒か：食道静眼㨨に対する胃上部切除 術. 手術, 30：461-469, 1976 .

6) 平野 裕：食道・胃手術前後飞的仔る下部食道 括約筋理 (lower esophageal sphincter pressure: LESP) の変動について。日臨外， $38: 767 一$ $778,1977$.

7) 小林迪夫ほか：肝障害例飞対する外科手術の適 応決定飞関するわれわれの見解. 日消外会誌， $7: 142-148,1974$.

8) 三戸康郎注か：食道静脈瘤汇対する内視鏡診 断. 臨外, $29: 173-179,1974$.

9）熊谷義也汪か：食道静脈䇡の内視鏡分類とその 臨床的意羲. 胃と腸, $11: 741-750,1976$.

10）吉村光政注食道静脈蜜に対する直達手術成 樍一とくに食道離断術について一. 外科, 38 : 797-801, 1976. 